\title{
AKTUALNE ASPEKTY FORMACJI PRZYSZŁYCH KAPŁANÓW
}

Badania socjologiczne wykazują, że kapłanowi w dzisiejszych czasach o wiele trudniej jest wykonywać swoją posługę duszpasterską, aniżeli jeszcze kilkadziesiąt lat temu. Przyczyn tego jest wiele: relatywizm moralny, skomplikowana sytuacja społeczna i polityczna, częste ukazywanie Kościoła w negatywnym świetle przez środki masowego przekazu, oraz coraz to nowe i trudniejsze wyzwania współczesności. W naszych czasach kapłan narażony jest również częściej na niepowodzenia w wypełnianiu swojej misji. $W$ obliczu tych trudności podejmuje on niekiedy dramatyczną decyzję porzucenia kapłaństwa.

W tej sytuacji właściwa formacja przyszłych kapłanów, którzy owocnie kontynuowaliby misję Jezusa Dobrego Pasterza we współczesnym świecie stanowi jedno z najważniejszych zadań Kościoła ${ }^{1}$.

* Ks. Ryszard Selejdak, dr hab. teologii, prezbiter archidiecezji częstochowskiej, patrysta i teolog dogmatyk; pracownik watykańskiej Kongregacji Edukacji Katolickiej. Od 1 marca 2002 r. dyrektor Departamentu Seminariów tejże Kongregacji.

${ }^{1}$ Por. B. Pitaud, La formation des futurs prêtres, un ministère spécifique au coeur de la vie de l'Eglise, "Seminarium” 2 (1994), s. 351-367; M. Gahunghu, V. Gambino, Formare i presbiteri. Principi e linee di metodologia pedagogica, Roma 2003, s. 23; A. Favale, Vocazione comune e vocazioni specifiche. Aspetti biblici, teologici e psico-pedagogico-pastorali, Roma 1981, s. $322-330$. 


\section{WYŻSZE SEMINARIA DUCHOWNE JAKO WŁAŚCIWE MIEJSCE PRZYGOTOWANIA PRZYSZKYCH KAPŁANÓW}

Wizytacje Apostolskie, przeprowadzone przez Kongregację Edukacji Katolickiej w ostatnich 30 latach niemal we wszystkich seminariach na całym świecie, ukazały, iż w niektórych Kościołach lokalnych próbuje się osłabić specyficzną rolę seminarium, jako niezbędnej instytucji powołanej do zapewnienia właściwej formacji kandydatom do kapłaństwa. W tym względzie uwidoczniły się takie niepokojące fakty jak: nieuzasadniony pobyt niektórych seminarzystów poza seminarium; obecność studentów świeckich w budynkach seminariów; próby zastępowania jednolitej wspólnoty seminarium małymi wspólnotami. W konsekwencji, pewna część seminarzystów mieszka w seminarium jedynie przez bardzo krótki okres czasu, a później mieszka poza nim, utrzymując jedynie sporadyczne kontakty z rektorem i ojcem duchownym.

Ponadto próbuje się wprowadzać nowe modele seminarium sprzeczne z modelem klasycznym, jak uczynił to na przykład w Paryżu kardynał Jean-Marie Lustiger. Ojciec Wojciech Giertych przedstawiając ten model pisze: „Seminarzyści najpierw spędzają razem rok w domu formacji, który spełnia funkcję analogiczną do nowicjatu zakonnego. Potem, na dalszych latach studiów, są oni przydzieleni do parafii paryskich i mieszkają na plebaniach, mając już pewne obowiązki duszpasterskie. W małej wspólnocie księży przy parafii łatwiej można poprowadzić i ocenić seminarzystów niż w dużej wspólnocie seminaryjnej. Na wspólne zajęcia zaś dojeżdżają oni, podobnie jak świeccy studenci, wygodnym paryskim metrem" ${ }^{\prime 2}$.

Wobec tej budzącej niepokój sytuacji należy promować z jeszcze większą determinacją i przekonaniem seminarium, jako uprzywilejowaną i konieczną instytucję dla formacji kapłańskiej, również w czasach nam współczesnych.

Już Sobór Watykański II w Dekrecie o formacji kapłańskiej Optatam totius stwierdził: „Do formacji kapłanów konieczne są wyższe seminaria”3 i nazywa je "sercem diecezji"

2 W. Giertych, Papieże bez seminarium, „Pastores” 47 (2010) 2, s. 28.

${ }^{3}$ Sobór Watykański II, Dekret o formacji kapłańskiej Optatam totius, 28.10.1965, n. 4, AAS 58 (1966) 716: tłum. pol., w: Sobór Watykański II, Konstytucje, Dekrety, Deklaracje, Poznań 2002, s. 291.

4 Tamże, n. 5, AAS 58 (1966) 717: tłum. pol., w: Sobór Watykański II, Konstytucje, Dekrety, Deklaracje, s. 291. 
Jan Paweł II w Adhortacji apostolskiej Pastores dabo vobis potwierdza konieczność wyższego seminarium duchownego dla formacji kapłańskiej, określając je jako „doskonałe miejsce formacji, [które] należy uznać za normalne środowisko - także $\mathrm{w}$ sensie materialnym - życia wspólnotowego i hierarchicznego, więcej - za prawdziwy dom formacyjny dla kandydatów do kapłaństwa, kierowany przez osoby rzeczywiście oddane tej służbie" ${ }^{\prime \prime}$.

Papież przytacza za Ojcami Synodu Biskupów także rację wynikającą z bardzo szerokiego doświadczenia: „Instytucja ta wydała w przeszłości i nadal wydaje obfite owoce na całym świecie" ${ }^{\prime \prime}$.

Ponadto Jan Paweł II ukazuje w sposób niezwykle jasny specyficzne cele seminarium wobec tendencji niewłaściwego go wykorzystywania. „Różnorakie przejawy życia seminarium jako wspólnoty wychowującej stuża formacji ludzkiej, duchowej, intelektualnej i duszpasterskiej przyszłych prezbiterów. Formacja ta ma wprawdzie wiele cech wspólnych z ludzką i chrześcijańską formacją wszystkich członków Kościoła, ale ma również specyficzne aspekty, treści i metody, wynikające z jej swoistego celu, jakim jest przygotowanie do kapłaństwa"7. Stąd treść i forma pracy wychowawczej winny być dokładnie zaprogramowane i zgodne $\mathrm{z}$, jedynym celem jego istnienia - przygotowaniem przyszłych kapłanów"8.

Jest sprawą oczywistą, iż możliwość skrócenia okresu pobytu seminarzystów $\mathrm{w}$ seminarium ${ }^{9}$ należy rozważać jako wyjątkową i tylko w szczególnie uzasadnionych przypadkach. Jeśli zaś chodzi o pobyt alumnów przez cały okres formacyjny $\mathrm{w}$ seminarium, to trzeba wiernie zachowywać wskazania soborowe, Ratio fundamentalis institutionis sacerdotalis i Adhortacji Pastores dabo vobis. Każda wspólnota seminaryjna, bez względu na jej wielkość, musi być podporządkowa wyłącznie formacji kapłańskiej i dlatego wymagana jest stała obecność w seminarium przynajmniej rektora, ojca duchownego i prefekta studiów.

${ }^{5}$ Jan Paweł II, Adhortacja apostolska posynodalna Pastores dabo vobis o formacji kapłanów we współczesnym świecie, 25.03.1992, Libreria Editrice Vaticana 1992, n. 60; por. także, Benedykt XVI, List do Seminarzystów, 18.10.2010, Watykan 2010, Wstęp, "L'Osservatore Romano", wyd. pol., 11 (2010), s. 4; Z. Grocholewski, Sacerdote e formazione al sacerdozio tra l'"Optatam totius" e il "Presbyterorum ordinis", "Seminarium" 3 (2005), s. 841 .

\footnotetext{
${ }^{6}$ Pastores dabo vobis, n. 60.

7 Tamże, n. 61.

8 Tamże.

${ }^{9}$ Por. Kodeks Prawa Kanonicznego, Poznań 1984, kan. 235.
} 


\section{POTRZEBA UKAZYWANIA TOŻSAMOŚCI KAPŁAŃSKIEJ ZGODNEJ Z NAUCZANIEM KOŚCIOŁA}

Nie ulega wątpliwości, iż jeszcze w czasach nam współczesnych są rozpowszechniane tu i ówdzie niektóre niejasne, czy też całkowicie błędne koncepcje tożsamości kapłańskiej. I tak na przykład propaguje się: koncepcję kapłaństwa jedynie funkcjonalnego; kapłaństwa czysto horyzontalnego; ideę kapłana rozumianego jako delegata wspólnoty wiernych dla zagwarantowania jej organizacji i wypełnienia jakiejś misji o charakterze czasowym; wizję indywidualistyczną kapłaństwa bez jakiegokolwiek odniesienia eklezjologicznego i nie mającego wpływu na problemy codziennego życia.

Ponadto, w środowiskach kościelnych często zapomina się, iż kapłaństwo wspólne wiernych różni się od kapłaństwa służebnego nie tylko stopniem, ale również istotą.

W takiej sytuacji biskup diecezjalny i wychowawcy seminaryjni powinni dołożyć wszelkich starań, aby seminarzystom była prezentowana tożsamość kapłana zgodna z nauczaniem Urzędu Nauczycielskiego Kościoła. Muszą oni jasno ukazywać różnicę ontologiczną pomiędzy kapłaństwem wspólnym wiernych a kapłaństwem służebnym, bazującym na specyficznym znamieniu wyciśniętym w sposób niezatarty na duszy wyświęconego przez sakrament święceń. Różnica ta ukazana jest bardzo wyraźnie w dokumentach soborowych i posoborowych.

W tym kontekście warto przytoczyć Konstytucję dogmatyczną o Kościele Lumen gentium, która ukazuje w bardzo zwięzły sposób rolę kapłanów i wylicza ich specyficzne zadania. Według niej kapłani „na mocy sakramentu kapłaństwa, na podobieństwo Chrystusa, Najwyższego i Wiekuistego Kapłana (Hbr 5, 1-10; 7, 24; 9, 11-28), są wyświęcani, aby głosić Ewangelię, być pasterzami wiernych i sprawować kult Boży jako prawdziwi kapłani Nowego Testamentu. Uczestnicząc zaś na swoim stopniu posługi w misji jedynego Pośrednika, Chrystusa (1 Tm 2, 5), głoszą wszystkim słowo Boże. Swoją świętą misję sprawują przede wszystkim w kulcie eucharystycznym, a zwłaszcza w Uczcie eucharystycznej, w której działając w osobie Chrystusa (in persona) i głosząc Jego misterium, łączą modlitwy wiernych z ofiarą Tego, który jest ich głową, i uobecniają w ofierze Mszy świętej aż do przyjścia Pana (por. 1 Kor 11, 26) jedyną ofiarę Nowego Testamentu, mianowicie Chrystusa ofiarującego siebie raz jeden Ojcu jako ofiarę nieskalaną (por. Hbr 9, 11-28), oraz rozdzielają owoce tej ofiary. Wobec wiernych zaś czyniących pokutę lub chorujących 
pełnią posługę jednania i niesienia ulgi, a potrzeby i modlitwy wiernych przedstawiają Bogu Ojcu (por. Hbr 5, 1-4). Wypełniając misję Chrystusa, Pasterza i Głowy, według posiadanego stopnia władzy, gromadzą rodzinę Bożą jako braci ożywionych duchem jedności i przez Chrystusa w Duchu prowadzą ją do Boga Ojca. Wśród trzody czczą Go w duchu i prawdzie (por. J 4, 24). Zajmują się wreszcie głoszeniem słowa i nauczaniem (por. 1 Tm 5, 17), wierząc w to, o czym rozważając, czytali w prawie Bożym, nauczając tego, w co uwierzyli, wypełniając to, czego nauczali"10.

Tożsamość kapłańska nakreślona przez cytowany dokument soborowy jest przekazana przez samego Chrystusa i winna być wiernie ukazywana przyszłym kapłanom. Od niej bowiem w ogromnej mierze zależy poprawność i skuteczność ich formacji ${ }^{11}$.

\section{DOGŁĘBNE ROZEZNANIE ZDATNOŚCI KANDYDATÓW}

Aktualna i bardzo złożona sytuacja młodzieży wymaga od wychowawców seminaryjnych dogłębnego rozeznania zdatności kandydatów do kapłaństwa w momencie ich przyjmowania do seminarium oraz promocji do święceń.

Kodeks Prawa Kanonicznego przypomina w tym względzie: „Do wyższego seminarium biskup diecezjalny powinien przyjmować jedynie tych, którzy, biorąc pod uwagę ich przymioty ludzkie i moralne, duchowe i intelektualne, ich zdrowie fizyczne i psychiczne, jak również szczerą wolę, wydają się być zdolni do oddania się na stałe świętym posługom"12. Równocześnie tenże Kodeks stanowi: „Do święceń należy dopuszczać jedynie tych, którzy - według roztropnej oceny własnego biskupa albo kompetentnego przełożonego wyższego - po rozważeniu wszystkich okoliczności, mają nieskażoną wiarę, kierują się prawidłową intencją, posiadają wymaganą wiedzę, cieszą się dobrą opinią, mają nienaganne

${ }^{10}$ Sobór Watykański II, Konstytucja dogmatyczna o Kościele Lumen gentium, 21.11.1964, n. 28, AAS 57 (1965) 34: tłum. pol., w: Sobór Watykański II, Konstytucje, Dekrety, Deklaracje, Poznań 2002, s. 291.

${ }^{11}$ Por. Pastores dabo vobis, n. 11b; por. także, Z. Grocholewski, Il Vescovo, la promozione delle vocazioni e la cura dei Seminari, w: Duc in altum. Pellegrinaggio alla Tomba di San Pietro. Incontro di riflessione. Roma 17-25 settembre 2006, Libreria Editrice Vaticana 2006, s. 83; tenże, Sacerdote e formazione al sacerdozio tra l'"Optatam totius" e il "Presbyterorum ordinis", s. 837.

${ }^{12}$ Kodeks Prawa Kanonicznego, kan. $241 \S 1$. 
obyczaje, wypróbowane cnoty, jak również inne przymioty fizyczne i psychiczne, odpowiadające przyjmowanemu święceniu"13.

Należy zauważyć, że w niektórych przypadkach, w selekcji kandydatów przed ich przyjęciem do seminarium lub dopuszczeniem do święceń, będzie konieczne poddanie ich testom psychologicznym. Zawsze jednak trzeba pamiętać, iż praktyka taka nie może być uogólniana i powinna być stosowana tylko w wyjątkowych, trudnych przypadkach (si casus ferat $)^{14}$. Ponadto należy z niej korzystać z wielką roztropnością, aby nie naruszyć prawa osoby do dobrego imienia oraz prawa do obrony własnej intymności. Oznacza to, że konsultację psychologiczną można będzie przeprowadzić tylko po wyrażeniu przez kandydata wcześniejszej, wyraźnej i całkowicie dobrowolnej na nią zgody. Kandydat będzie mógł zwrócić się w sposób dobrowolny albo do specjalisty psychologa wybranego spośród tych wskazanych przez wychowawców, albo też wybranego przez samego siebie i zaakceptowanego przez wychowawców. W przypadku, gdyby kandydat odrzucił dobrze umotywowaną prośbę wychowawców poddania się konsultacji psychologicznej, ci w żaden sposób nie mogą wywierać na niego presji. Powinni natomiast kontynuować rozeznanie jego zdatności, korzystając z posiadanej o nim wiedzy i mając na uwadze zarządzenie kan. 1052 § 1, według, którego zdatność kandydata musi być potwierdzona pozytywnymi argumentami. Ponadto wychowawcy winni się upewnić, iż kandydat wybiera kapłaństwo, kierując się wyłącznie motywami ewangelicznymi ${ }^{15}$.

W tym kontekście szczególną uwagę winno się zwrócić na przyjmowanie do seminarium kandydatów, pochodzących z innych seminariów diecezjalnych lub instytutów zakonnych.

Kongregacja Edukacji Katolickiej poświęciła temu delikatnemu problemowi list okólny ${ }^{16}$ oraz instrukcję ${ }^{17}$. W nich przypomina biskupom

13 Tamże, kan. 1029.

${ }^{14}$ Por. Congregazione per l'Educazione Cattolica, Ratio fundamentalis institutionis sacerdotalis, 6.01 .1970 (wersja uaktualizowana, 19.03.1985), n. 39.

${ }^{15}$ Por. Congregazione per l'Educazione Cattolica, Orientamenti per l'utilizzo delle competenze psicologiche nell'ammissione e nella formazione dei candidati al sacerdozio, 29.06.2008, Città del Vaticano 2008, n. 11-12; Kodeks Prawa Kanonicznego, kan. 220.

${ }^{16}$ Por. Congregazione per l'Educazione Cattolica, Lettera circolare Ci permettiamo, ai Rappresentanti Pontifici, circa l'ammissione di ex-seminaristi in altro seminario, 9.10.1986, w: EV 10, n. 949-952.

${ }^{17}$ Por. Congregazione per l'Educazione Cattolica, Istruzione Con la presente sull'ammissione al seminario di candidati provenienti da altri seminari o famiglie religiose, 8.03.1996, w: EV 15, n. 384-394. 
obowiązek dokładnej aplikacji kan. 241 § 3 przy przyjmowaniu do seminarium seminarzystów wydalonych $\mathrm{z}$ innego seminarium lub instytutu zakonnego. Kongregacja odwołuje się przy tym do normy wyrażonej w numerze 39 Ratio fundamentalis institutionis sacerdotalis: „Gravis incumbit episcopis obligatio investigandi praesertim de causis dimissionis eorum, qui ex alieno seminario vel instituto religioso dimissi fuerint"18.

To odwołanie jest szczególnie ważne, ponieważ doświadczenie pokazuje, iż wspomniana norma nie jest odpowiednio przestrzegana. Istotnie, już w pierwszym z przytoczonych dokumentów Kongregacja zauważyła: „Jest wielu biskupów i rektorów seminariów, którzy ubolewają z powodu zbyt łatwego przyjmowania do innych seminariów seminarzystów przez nich wydalonych bez proszenia przez ordynariusza a quo informacji odnośnie przymiotów duchowych, ludzkich i intelektualnych takich kandydatów oraz przyczyn ich wydalenia z seminarium. W takich przypadkach cierpi głównie prestiż i autorytet biskupów i rektorów, którzy usiłują aplikować w rozeznaniu powołania właściwych kryteriów selekcji, a przede wszystkim prestiż samego Kościoła, któremu są dani w ten sposób pasterze nie nadający się do podjęcia świętego posługiwania"19.

Ponadto Kongregacja zaleca, aby Konferencje Biskupie poszczególnych krajów „opracowały w tym względzie bardziej szczegółowe i dostosowane do sytuacji lokalnej normy i procedury, umieszczając je w narodowych Rationes institutionis sacerdotalis w rozdziale poświęconym seminarzystom. Jest rzeczą oczywistą, iż wspomniany problem dotyczy nie tylko wydalonych seminarzystów, lecz także tych, którzy z własnej woli opuścili seminarium, często po to, aby uniknąć formalnego wydalenia" ${ }^{20}$.

Wspomniana problematyka, choć nie całkiem nowa, pozostaje ciągle aktualną. Istotnie, w ostatnich latach obserwuje się wzmożoną „migrację" seminarzystów nie tylko w granicach jednego kraju, lecz także przekraczającą granice poszczególnych krajów i kontynentów, jak na przykład z Europy Wschodniej i z Ameryki Południowej do Europy Zachodniej czy też do Stanów Zjednoczonych.

Wreszcie, bardzo dużą uwagę należy zwrócić przy przyjmowaniu do seminarium i dopuszczeniu do święceń kandydatów z tendencjami

\footnotetext{
${ }^{18}$ Lettera circolare Ci permettiamo, n. 951; Istruzione Con la presente, n. 388.

${ }^{19}$ Lettera circolare Ci permettiamo, n. 950 - tłum. własne.

${ }^{20}$ Tamże, n. 952 - tłum. własne.
} 
homoseksualnymi. W tym względzie Kongregacja Edukacji Katolickiej oświadcza wyraźnie, iż „Kościól, głęboko szanując osoby, których dotyczy ten problem, nie może przyjmować do seminarium ani do święceń osób, które praktykują homoseksualizm, wykazują głęboko zakorzenione tendencje homoseksualne lub wspierają tak zwaną "kulturę gejowską»" 21. Według Kongregacji inaczej natomiast należałoby traktować kandydatów o tendencjach homoseksualnych, „które są jedynie wyrazem przejściowego problemu, takiego jak, na przykład, niezakończony jeszcze proces dojrzewania. Niemniej jednak, takie tendencje muszą być wyraźnie przezwyciężone, przynajmniej trzy lata przed święceniami diakonatu"22. Do kierownika duchowego należy obowiązek oceny wszelkich cech osobowości kandydata i upewnienie się, że nie występują u niego zaburzenia natury seksualnej, które są nie do pogodzenia z kapłaństwem. W przypadku uprawiania przez kandydata homoseksualizmu albo wykazywania przez niego głęboko zakorzenionych tendencji homoseksulanych, jego kierownik duchowy, a także spowiednik są zobowiązani w sumieniu odwieźć go od ubiegania się o święcenia ${ }^{23}$.

\section{OKRES PROPEDEUTYCZNY}

Wprowadzenie okresu wstępnego, poprzedzającego właściwą formację w seminariach, zalecał już Sobór Watykański II. W Dekrecie o formacji kapłańskiej Optatam totius stwierdza: „alumni [...] powinni studia teologiczne rozpocząć od odpowiednio długiego kursu wstępnego. W tym wprowadzeniu trzeba tak przedstawić historię zbawienia, aby alumni dostrzegli znaczenie studiów kościelnych, ich porządek i duszpasterski cel, a zarazem mieli podstawę, by własne życie w całości budować na wierze i jej pozwolić je przenikać oraz aby zostali umocnieni w przyjęciu powołania przez osobiste oddanie się Kościołowi w radości ducha" ${ }^{24}$.

${ }^{21}$ Kongregacja Edukacji Katolickiej, Instrukcja na temat kryteriów rozeznawania powołania u osób z tendencjami homoseksualnymi ubiegających się o przyjęcie do seminarium i dopuszczenie do święceń, 4.11.2005, Rzym 2005, n. 2, "L'Osservatore Romano", wyd. pol., 5 (2006), s. 54.

${ }^{22}$ Tamże.

${ }^{23}$ Por. tamże, n. 3, s. 55.

${ }^{24}$ Optatam totius, n. 14, AAS 58 (1966) 722: tłum. pol., w: Sobór Watykański II, Konstytucje, Dekrety, Deklaracje, s. 296. 
Również Jan Paweł II w Adhortacji apostolskiej Pastores dabo vobis pisze: " "Jest rzeczą wskazaną, aby kandydaci do wyższego seminarium przeszli najpierw wstępną formację ludzką, chrześcijańską, intelektualną i duchową»" 25. Papież nazywa ten okres wstępny „okresem propedeutycznym"26.

Nie ulega wątpliwości, że złożoność seminaryjnego procesu formacyjnego, występujące u kandydatów do kapłaństwa poważne braki w zakresie przygotowania duchowego i kulturowego, często ich niedojrzałość osobowościowa, mała odporność psychiczna, pochodzenie z rodzin rozbitych, naznaczonych alkoholizmem i obojętnością religijną wskazują na konieczność zagwarantowania im odpowiedniego przygotowania w czasie okresu propedeutycznego, poprzedzającego formację w seminarium. Inicjatywa ta jest dostrzegana jako bardzo użyteczna niemal we wszystkich Kościołach lokalnych, a nieraz uważa się ją wręcz za "conditio sine qua non" dla podniesienia ogólnego poziomu formacji kapłańskiej.

Obecnie w Kościołach lokalnych są praktykowane trzy podstawowe typy okresu propedeutycznego. Są to: okres propedeutyczny autonomiczny, okres propedeutyczny zintegrowany z wyższym lub niższym seminarium oraz okres propedeutyczny powiązany $z$ duszpasterstwem powołaniowym ${ }^{27}$.

Okres propedeutyczny autonomiczny jest organizowany w specjalnym Seminarium Propedeutycznym, które pragnie pomóc kandydatom do kapłaństwa w rozeznaniu powołania, uzupełnieniu braków w dojrzałości ludzkiej, religijno-duchowej oraz w przygotowaniu intelektualnym. Wspomniane Seminarium Propedeutyczne jest instytucją autonomiczną, kierowaną przez własny zespół wychowawczy. Okres propedeutyczny trwa w nim co najmniej dwa lata i przygotowuje młodych do podjęcia dwuletnich studiów filozoficznych ${ }^{28}$.

Okres propedeutyczny zintegrowany z wyższym seminarium jest poświęcony przede wszystkim pogłębieniu wiary i życia ducho-

${ }^{25}$ Pastores dabo vobis, n. 62.

${ }^{26}$ Tamże; por. M. Maciel, La formazione integrale del sacerdote, Roma 1991, s. 264; D. Negro, Anno propedeutico: vera novità del Concilio Vaticano II, „Seminarium” 32 (1992) 4, s. 600-621; M. Biskup, Annus propedeuticus w formacji seminaryjnej - eksperyment czy konieczność, „Ateneum Kapłańskie” 120 (1993), s. 470-474; A. Orczyk, Il rinnovamento della formazione seminaristica, Roma 1997, s. 136-139.

${ }^{27}$ Por. Congregazione per l'Educazione Cattolica, Il periodo propedeutico, 1.05.1998, Città del Vaticano 1998, s. 13.

${ }^{28}$ Por. tamże, s. 14. 
wego alumnów poprzez uczestnictwo w celebracji Eucharystii, Liturgii Godzin, oraz świętowaniu najważniejszych świąt roku liturgicznego. Ponadto, w programie tego okresu uwzględnia się formację doktrynalną i ludzką oraz wprowadzenie w problemy duszpasterskie. Okres ten trwa zazwyczaj jeden rok. Sa jednak kraje gdzie, trwa on zaledwie od dwóch do czterech tygodni. Wspomniany okres poprzedza dwuletni cykl filozoficzny ${ }^{29}$.

Trzeci praktykowany okres propedeutyczny połączony z duszpasterstwem powołaniowym, w odróżnieniu od dwóch wcześniej wspomnianych, nie ma charakteru instytucjonalnego. Zazwyczaj diecezjalne ośrodki duszpasterstwa powołaniowego organizują dla młodych okresowe spotkania formacyjne i dni skupienia. W ten sposób chce się pomóc młodym ludziom $\mathrm{w}$ rozeznawaniu powołania, zapewnić im kierownictwo duchowe oraz wprowdzić w modlitwę i życie sakramentalne ${ }^{30}$.

Nie ulega wątpliwości, że organizowane okresy propedeutyczne są bardzo użyteczne i na czasie, nawet jeśli ich przeprowadzenie nie zawsze jest łatwe z powodu braku odpowiednich lokali, zespołu wychowawców i środków finansowych. Istotnie $\mathrm{w}$ wielu krajach konkretne okoliczności wymagają ścisłej współpracy między diecezjami w celu organizacji okresów propedeutycznych regionalnych lub krajowych, za które biorą odpowiedzialność biskupi danych regionów lub Konferencja Biskupów.

Należy podkreślić, że przy organizacji okresów propedeutycznych winno się zwrócić szczególną uwagę na zagwarantowanie odpowiedniej równowagi między elementami ludzko-duchowymi a kulturowymi, dla uniknięcia przesadnego mnożenia wykładanych przedmiotów kosztem formacji religijnej i kapłańskiej.

Ponadto doświadczenia pokazują, że pomimo wielu podjętych wysilków, różne modele okresów propedeutycznych poprzedzające wstąpienie do wyższego seminarium nie są $\mathrm{w}$ stanie rozwiązać wszystkich problemów związanych z dojrzałością ludzką i rozeznaniem powołania kandydatów do kapłaństwa. Dlatego też w wielu krajach, po dwóch lub trzech latach, przerywa się cykl formacji seminaryjnej i alumni odbywają, różnie nazywany, specjalny staż poza seminarium („Pastoral Internship”, „Spirituality-Pastoral Year", „Freijahr”, „Externjahr”) ${ }^{31}$.

\footnotetext{
${ }^{29}$ Por. tamże, s. 28.

${ }^{30}$ Por. tamże, s. 31-33.

31 Por. tamże, s. 35-37.
} 


\section{INTEGRALNA FORMACJA KAPŁAŃSKA}

W Adhortacji apostolskiej Pastores dabo vobis Jan Paweł II wskazuje na potrzebę zagwarantowania przyszłym kapłanom formacji integralnej. Zdaniem Papieża formacja taka winna obejmować wymiary ludzki, duchowy, intelektualny i duszpasterski, wzajemnie ze sobą połączone i uzupełniające się.

\subsection{FORMACJA LUDZKA}

Formacja ludzka stanowi fundament całej formacji kapłańskiej ${ }^{32}$. „Kapłan - stwierdza Jan Paweł II - powołany do tego, by «być żywym obrazem» Jezusa Chrystusa Głowy i Pasterza Kościoła, powinien starać się odtworzyć w sobie, w miarę możliwości, ludzką doskonałość jaśniejącą w Synu Bożym, który stał się człowiekiem, ujawniającą się szczególnie wyraźnie w Jego postawie wobec innych, tak jak ukazują to Ewangeliści"33.

Jezus Chrystus winien więc stanowić dla każdego seminarzysty wzór oraz źródło doskonałości ludzkiej i chrześcijańskiej. To, co jako przyszły kapłan będzie mówił i czynił, ma być tym wszystkim czego nauczał Jezus Chrystus i tym wszystkim co czynił On ludziom. Alumn nie może zapomnieć, że ma stać się żywym sakramentem obecności kapłańskiej Chrystusa w Kościele.

Według nauki Jana Pawła II, zadania formacji ludzkiej wypływają ze specyfiki posługi kapłańskiej wymagającej ludzkiej osobowości, która byłaby dla ludzi pomostem, a nie przeszkodą w spotkaniu się z Chrystusem ${ }^{34}$. Dlatego też kandydaci do kapłaństwa „powinni rozwijać w sobie zespół ludzkich cech, bez których nie można kształtować osobowości zrównoważonych, silnych i wolnych, zdolnych dźwigać ciężary duszpasterskiej odpowiedzialności. Potrzebne jest więc wychowanie do umiłowania prawdy, do prawości i rzetelności, do szacunku wobec każdej osoby, do poczucia sprawiedliwości, do wierności danemu słowu, do prawdziwego współczucia, do konsekwentnego postępowania, a zwłaszcza do zrównoważonego sądu i zachowania"35.

\footnotetext{
${ }^{32}$ Por. Pastores dabo vobis, n. 43.

${ }^{33}$ Tamże.

${ }^{34}$ Por. tamże.

${ }^{35}$ Tamże.
} 
Adhortacja apostolska Pastores dabo vobis wskazuje więc na liczne i różnorodne aspekty formacji ludzkiej. Obejmują one między innymi formowanie do odpowiedzialnej wolności, kształtowanie sumienia moralnego, dojrzałości uczuciowej oraz zdolności do nawiązywania i utrzymywania kontaktów z innymi ${ }^{36}$.

Nie ulega wątpliwości, iż w dzisiejszych czasach szczególny nacisk należy położyć na wychowanie seminarzysty do życia w celibacie. Coraz więcej bowiem alumnów w niewłaściwy sposób rozumie celibat kapłański, ma kłopoty z podjęciem decyzji do życia w nim, a następnie do zachowywania go. $\mathrm{W}$ tej sytuacji zagadnienie celibatu trzeba koniecznie podejmować w całej jego głębi.

Jan Paweł II zachęca, aby problematykę wychowania do życia w celibacie ukazywać mając zawsze na uwadze aktualną sytuację społeczno-kulturową: „Biskupi wraz z rektorami i ojcami duchownymi seminariów niech ustalą zasady, przedstawią kryteria i wskażą metody rozeznania $\mathrm{w}$ tej materii. $\mathrm{W}$ formacji do czystości $\mathrm{w}$ celibacie ogromnie ważna jest troska biskupa o braterskie współżycie kapłanów. W seminarium, w jego programie formacyjnym, trzeba ukazywać celibat jasno, bez żadnej dwuznaczności i w sposób pozytywny"37.

Z kolei Benedykt XVI, wyrażając głęboki ból i żal z powodu nadużyć seksualnych, których dopuścili się niektórzy kapłani wobec dzieci i młodzieży, wzywa wychowawców seminaryjnych i spowiedników, aby z ogromną uwagą i czujnością towarzyszli i pomagali kandydatom do kapłaństwa w rozeznawaniu ich powołania do życia w celibacie ${ }^{38}$.

W wychowaniu do czystości w celibacie należy również przedstawiać celibat jako cenny dar Boży, o który trzeba się modlić każdego dnia. Może on być bowiem przeżyty należycie jedynie w kapłaństwie głęboko zakorzenionym $\mathrm{w}$ nadprzyrodzoności ${ }^{39}$.

Dekret soborowy o posłudze i życiu kapłanów Presbyterorum ordinis zaznacza, iż celibat, choć nie jest wymagany z samej natury kapłaństwa, był jednak zawsze $\mathrm{w}$ szczególny sposób ceniony w perspektywie życia kapłańskiego. Jest on „bowiem znakiem, a jednocześnie bodźcem miłości pasterskiej i szczególnym źródłem duchowej płodności w świecie".

${ }^{36}$ Por. tamże, n. 43-44.

37 Tamże, n. 50.

${ }^{38}$ Por. Benedykt XVI, List do Seminarzystów, n. 6, s. 6-7.

${ }^{39}$ Por. Optatam totius, n. 10, AAS 58 (1966) 719-720: tłum. pol., w: Sobór Watykański II, Konstytucje, Dekrety, Deklaracje, s. 294-295. 
Dlatego też „z wielu względów odpowiada kapłaństwu”"40. Poprzez życie w celibacie kapłani w wyjątkowy sposób poświęcają się Chrystusowi, łatwiej z niepodzielonym sercem trwają przy Nim, z większą wolnością mogą poświęcać się Bogu i ludziom, sprawniej angażują się w służbę dla Królestwa Bożego, a w konsekwencji są bardziej zdatni do przyjęcia duchowego ojcostwa. Celibat jest ponadto znakiem dla wiernych, że kapłani w sposób całkowity chcą się poświęcić zadaniom wynikającym z przyjętych święceń. Wreszcie, są oni zapowiedzią nowego świata, w którym ustaną wszelkie potrzeby, bo tam ani nie będą wychodzić za mąż, ani się nie będą żenić (por. Mt 22, 30; Mk 12, 25; Łk 20, 35). Sobór w sposób jednoznaczny uznaje i potwierdza obowiązek zachowania celibatu przez tych, którzy pragną przyjąć święcenia kapłańskie w Kościele łacińskim. Jednocześnie wyraża nadzieję, że daru celibatu Bóg udzieli wielkodusznie, jeśli tylko cały Kościół, a zwłaszcza kapłani będą o niego usilnie prosić ${ }^{41}$.

Formacja do czystości w celibacie musi więc posiadać cele bardzo jasno określone i należy zweryfikować ich osiągnięcie przez przyszłych kapłanów z możliwie jak największą pewnością. Nie byłoby bowiem rzeczą roztropną dopuszczać do święceń seminarzystów, którzy wykazują trudności w tej materii. W takich przypadkach wychowawcy seminaryjni winni mieć odwagę do natychmiastowego wskazania zainteresowanym innych dróg, niż podtrzymywać w nich niepotrzebne złudzenia.

${ }^{40}$ Sobór Watykański II, Dekret o posłudze i życiu kapłanów Presbyterorum ordinis, 7.12.1965, n. 16, AAS 58 (1966) 1015: tłum. pol., w: Sobór Watykański II, Konstytucje, Dekrety, Deklaracje, Poznań 2002, s. 500; por. także, J. Wątroba, Permanentna formacja duchowa kaptanów w świetle soborowych i posoborowych dokumentów Urzędu Nauczycielskiego Kościota (1963-1994), Częstochowa 1999, s. 153; K. Boryna, Ciagłość formacji kapłańskiej. Studium wedtug Dokumentów Nauczycielskiego Urzędu Kościoła od Soboru Watykańskiego II do VIII Zwyczajnego Synodu Biskupów, Lublin 1992, s. 228; G. Greshake, Być kaptanem. Teologia i duchowość urzędu kaptańskiego, tłum. pol., K. Wójtowicz, Wrocław 1983, s. 147-148.

${ }^{41}$ Por. Presbyterorum ordinis, n. 16, AAS 58 (1966) 1015: tłum. pol., w: Sobór Watykański II, Konstytucje, Dekrety, Deklaracje, s. 500; por. także, J. Wątroba, Permanentna formacja duchowa kaptanów, s. 153; M. Caprioli, Il sacerdozio. Teologia e spiritualità, Roma 1992, s. 241; K. Hołda, Rady ewangeliczne w wewnętrznym życiu kapłana, „Ateneum Kapłańskie” 87 (1976), s. 43-45; J. Ferreira Pena, Fondamenti dottrinali del celibato ecclesiastico, „Periodica" 83 (1994), s. 237; S. Garofalo, Introduzione alla lettura dell'Enciclica "Sacerdotalis caelibatus", "Seminarium" 4 (1967), s. 764-773; G. Oggioni, Il celibato sacerdotale: aspetti escatologici, "Seminarium” 4 (1967), s. 807-824; L. Scheffczyk, Der Zölibat: Formkraft priestlicher Existenz und priestlicher Dienst, "Seminarium” 1 (1993), s. 48-59; R. Spiazzi, I consigli evangelici nella vita sacerdotale, "Seminarium" 4 (1966), s. 1004-1019. 


\subsection{FORMACJA DUCHOWA}

Formacja ludzka, zakorzeniona $\mathrm{w}$ antropologii przyjmującej pełną prawdę o człowieku, otwiera się i znajduje swe dopełnienie $\mathrm{w}$ formacji duchowej, która stanowi niejako serce całej formacji kapłańskiej i jest zarówno elementem jednoczącym jak i ożywiającym tożsamość i posłannictwo każdego kapłana. Jej celem jest ustanowienie głębokiej więzi między kandydatem do kapłaństwa a Jezusem Chrystusem Dobrym Pasterzem ${ }^{42}$.

Wychowawcy powinni więc przede wszystkim nauczyć seminarzystów zażyłości ze Słowem Bożym. Właściwe podejście do Słowa Bożego „pozwala [bowiem] spotkać się z samym Bogiem, z Bogiem przemawiającym do człowieka. Pozwala [...] spotkać się z Chrystusem, Słowem Bożym, z Prawdą, która równocześnie jest Drogą i Życiem"43. Ponadto „W świetle i w mocy Słowa Bożego można [...] odkryć, zrozumieć i pokochać własne powołanie, pójść za nim i wypełnić swoją misję"44. „Pełne miłości poznanie i modlitewna zażyłość ze Słowem Bożym mają szczególne znaczenie dla prorockiej posługi kapłana: stają się nieodzownym warunkiem właściwego jej wypełnienia, zwłaszcza w kontekście «nowej ewangelizacji», do której Kościół jest dziś powołany"45.

„Pierwszą [zaś] i podstawową formą odpowiedzi na Słowo jest modlitwa, która bez wątpienia - jak czytamy w Pastores dabo vobis - stanowi naczelną wartość i nakaz formacji duchowej" ${ }^{\prime \prime 6}$. Jan Paweł II z wielką wnikliwością dodaje: „Formacja ta powinna prowadzić przyszłych kapłanów do poznania i doświadczenia autentycznego sensu modlitwy chrześcijańskiej, zgodnie z którym jest ona żywym i osobistym spotkaniem z Ojcem przez Jednorodzonego Syna pod działaniem Ducha Świętego, dialogiem włączonym w synowską rozmowę, jaką Jezus prowadzi z Ojcem" ${ }^{\prime 47}$. Stąd Papież przypomina, iż „,każdego dnia trzeba na nowo dochowywać zewnętrznej wierności momentom modlitwy, zwłaszcza poświęconym sprawowaniu

${ }^{42}$ Por. Pastores dabo vobis, n. 45; por. także, Z. Grocholewski, Sacerdote e formazione al sacerdozio tra l'"Optatam totius" e il "Presbyterorum ordinis", art. cyt., s. 839; tenże, La vita spirituale "centro della formazione sacerdotale", "Seminarium" 4 (2004), s. 775-776.

${ }^{43}$ Pastores dabo vobis, n. 47.

${ }^{44}$ Tamże.

${ }^{45}$ Tamże.

${ }^{46}$ Tamże.

${ }^{47}$ Tamże. 
Liturgii Godzin, a także pozostawionym osobistemu wyborowi, nie wyznaczonym przez rytm służby liturgicznej"48.

Zadaniem wychowawców seminaryjnych, zwłaszcza ojców duchownych, jest udzielenie seminarzystom niezbędnej pomocy, aby umiłowali oni modlitwę i by kiedyś, jako kapłani, mogli stać się jej nauczycielami. Istotnie, tylko kapłan, który był formowany i kontynuuje swoją formację w szkole modlącego się Jezusa będzie mógł formować innych $\mathrm{w}$ tej samej szkole ${ }^{49}$.

W tym kontekście należy podkreślić też konieczność wyrabiania $\mathrm{w}$ alumnach umiejętności zachowywania milczenia.

Ratio fundamentalis institutionis sacerdotalis zaleca seminarzystom, aby wpatrzeni w przykład Chrystusa szukającego samotności, by móc się modlić, cenili sobie i troszczyli się o zachowanie milczenia zewnętrznego, bez którego trudno byłoby mówić o milczeniu wewnętrznym ${ }^{50}$.

Podobne znaczenie milczenia $\mathrm{w}$ pedagogii modlitwy widzi Jan Paweł II. W Adhortacji Pastores dabo vobis zauważa: „Pośród niepokoju i zgiełku panującego w naszym społeczeństwie, koniecznym elementem pedagogii modlitwy jest ukazywanie głębokiego ludzkiego sensu i religijnej wartości milczenia jako atmosfery duchowej nieodzownej do tego, by odczuć obecność Boga i w niej się zanurzyć" ${ }^{\prime \prime 1}$.

„Szczytem chrześcijańskiej modlitwy jest Eucharystia"52, przypomina Pastores dabo vobis, i zarazem umieszcza Eucharystię w żywotnym kontekście przeżywania sakramentów i Liturgii Godzin, których jest ona także „szczytem $i$ źródtem" ${ }^{\prime 53}$. Stąd, zaznacza wspomniany dokument, „kapłani, jako szafarze rzeczy świętych, są przede wszystkim sługami ofiary Mszy św. Ich rola jest absolutnie niezastąpiona, ponieważ bez kapłana nie ma ofiary eucharystycznej. Stanowi to wyjaśnienie istotnego znaczenia Eucharystii dla życia i posługi kapłańskiej i tym samym dla formacji duchowej kandydatów do kapłaństwa" ${ }^{24}$.

W związku z tym Papież domaga się nie tylko, by codzienne uczestniczenie seminarzystów w Eucharystii stało się później „regułą ich

${ }^{48}$ Tamże, n. 72 e; por. także, Benedykt XVI, List do Seminarzystów, n. 1, s. 4

${ }^{49}$ Por. Pastores dabo vobis, n. 47.

${ }^{50}$ Por. Ratio fundamentalis institutionis sacerdotalis, n. 57.

${ }^{51}$ Pastores dabo vobis, n. 47 e; por także, List apostolski Novo millennio ineunte, 6.01.2001, Libreria Editrice Vaticana 2001, n. 20.

${ }^{52}$ Pastores dabo vobis, n. 48.

${ }^{53}$ Tamże.

${ }^{54}$ Tamże. 
kapłańskiego życia", ale również, by "tak ich wychowywać, aby Eucharystia była dla nich najważniejszym wydarzeniem dnia, by umieli w niej aktywnie uczestniczyć, nie ograniczając się nigdy do samej rutyny", aby „kształtować u kandydatów do kapłaństwa wewenętrzne postawy, dla których oparciem jest Eucharystia" ${ }^{\prime \prime 5}$.

Jan Paweł II podkreśla, że Jezus obecny w Eucharystii jest dla przyszłych kapłanów także najdoskonalszym wzorem cnót nadprzyrodzonych i ludzkich, którymi powinni odznaczać się w swoim życiu. Kontakt z Nim przez formację duchową, pozwala im uporządkować uczucia i pragnienia, uformować własny charakter, rozwinąć cnoty, które będą ich upodabniać do postawy Chrystusa ${ }^{56}$.

Mając na uwadze naturę i znaczenie tego sakramentu, chodzi o rzecz ogromnej wagi. Katechizm Kościoła Katolickiego, odwołując się do Soboru Watykańskiego II, stwierdza: „Eucharystia jest źródłem i zarazem szczytem całego życia chrześcijańskiego. Inne zaś sakramenty, tak jak wszystkie kościelne posługi i dzieła apostolstwa, wiążą się ze świętą Eucharystią i do niej zmierzają"57.

Należy więc w seminarium nauczyć alumnów rozumieć, kochać i przeżywać Eucharystię, aby stawała się ona dla nich coraz bardziej „źródłem i szczytem” ich całej duchowości i apostolstwa.

W formacji duchowej niezwykle konieczna i pilna jest także pomoc alumnom w ponownym odkryciu "piękna i radości sakramentu pokuty”"58.

${ }^{55}$ Tamże; por. także, Benedykt XVI, List do Seminarzystów, n. 2, s. 5.

${ }^{56}$ Por. Pastores dabo vobis, n. 48; por. także, J. Wright, Priestly maturity, "Seminarium" 10 (1970), s. 820-821; C. A. Bernard, Teologia spirituale, Roma 1983, s. 305; J. Martin Abad, La esperitualidad sacerdotal en la formaciòn para el ministero presbiteral, w: Espiritualidad del presbitero diocesano secular, Madrid 1987, s. 527; L. Rubbio Parrado, Ministros de Cristo y administradores de los ministerios de Dios, „Seminarium” 1-2 (1990), s. 156-158; A. H. Ca-sero, La formaciòn espiritual en la exhortaciòn Pastores dabo vobis, "Seminarios" 39 (1993), s. 303-329; V. Gambino, La formazione spirituale del presbitero: configurazione a Cristo, "Salesianum" 55 (1993), s. 194; I. Peri, I seminari oggi. La formazione dei sacerdoti nelle circostanze attuali, Roma 1995, s. 255; V. Fagiolo, La spiritualità del prete diocesano, Roma 1995, s. 79-84; E. Martinez Somalo, Considerate la vostra vocazione. Meditazioni sul sacerdozio, „Rivista di Vita Spirituale” 51 (1997), s. 67-68; M. Kaczmarek, Ku doskonatości kaptana, Częstochowa 1997, s. 99; J. Koperek, Prawda i miłość w życiu eucharystycznym kaptana, „Dobry Pasterz” 16 (1995), s. 98-112; K. Dyrek, Formacja ludzka w wychowaniu seminaryjnym do kaptaństwa w świetle dokumentów posoborowych Kościoła i literatury teologicznej (1967-1997), Warszawa 1998, s. 279.

${ }^{57}$ Katechizm Kościoła Katolickiego, Poznań 1994, n. 1324.

${ }^{58}$ Pastores dabo vobis, n. 48; por. także, F. Rypar, Il sacramento della penitenza nella formazione dei futuri sacerdoti, „Seminarium” 3 (1973), s. 598; R. Selejdak, Stawać się kaptanem trzeciego tysiąclecia, Częstochowa 2001, s. 55. 
Jest to zadanie wychowawców mające wielkie znaczenie zwłaszcza w kulturze nam współczesnej, charakteryzującej się coraz to nowymi, a przy tym coraz bardziej wyrafinowanymi formami samousprawiedliwienia i w związku z tym narażonej na zgubną utratę poczucia grzechu, a $\mathrm{w}$ konsekwencji również radości i pociechy, którą przynosi prośba o przebaczenie ${ }^{59}$. Ponadto zadanie to podyktowane jest potrzebą odkrywania sensu „ascezy i wewnętrznej dyscypliny, ducha ofiary i wyrzeczenia, zgody na przyjęcie trudów i krzyża"60.

Jest rzeczą oczywistą, iż kandydaci do kapłaństwa nie będą mogli stać się dobrymi i skutecznymi szafarzami pokuty oraz wiarygodnymi świadkami miłosierdzia Bożego dla grzeszników, o ile wpierw sami z niego nie będą korzystali61 ${ }^{6}$ Tę myśl wyraził już Jan Paweł II w Adhortacji Reconciliatio et paenitentia. Pisał tam, że "duchowe i apostolskie życie kapłana, podobnie jak jego braci świeckich i zakonnych, poziom tego życia i jego żarliwość, zależy od wytrwałego i sumiennego korzystania z sakramentu pokuty. Sprawowanie Eucharystii i szafarstwo innych sakramentów, zapał duszpasterski, stosunki z wiernymi, komunia ze współbraćmi, współpraca z biskupem, życie modlitwy, jednym słowem całe życie kapłańskie nieubłaganie doznaje uszczerbku, jeśli brak w nim wskutek niedbalstwa, czy z innych przyczyn, regularnego, przenikniętego autentyczną wiarą i pobożnością zwrócenia się do sakramentu pokuty. Gdyby jakiś ksiądz nie spowiadał się lub spowiadał się źle, bardzo szybko odbiłoby się to na samym jego kapłaństwie i sprawowaniu kapłaństwa, co dostrzegłaby również Wspólnota, której jest pasterzem"62.

Do wielkiego znaczenia sakramentu pokuty w formacji przyszłych kapłanów nawiązuje niejednokrotnie również Benedykt $\mathrm{XVI}^{63}$. W Liście do Seminarzystów podkreśla, iż sakrament pokuty uczy seminarzystę obiektywnej oceny samego siebie, pomaga w zajmowaniu postawy pełnej

${ }^{59}$ Por. Pastores dabo vobis, n. 48.

${ }^{60}$ Tamże.

${ }^{61}$ Por. tamże, n. 26.

${ }^{62}$ Jan Paweł II, Adhortacja apostolska Reconciliatio et paenitentia, 2.12.1984, Libreria Editrice Vaticana 1984, n. 31; por. także, Pastores dabo vobis, n. 26.

${ }^{63}$ Por. Benedykt XVI, Il sì del sacerdozio mi ha accompagnato ogni giorno della mia vita. Visita alla comunità del Pontificio Seminario Romano Maggiore in occasione della Festa Patronale della Madonna della Fiducia, Roma, 17.02.2007, „Insegnamenti” 3 (2007) 1, s. 239-240; Nuovi testimoni del Vangelo nelle strade e nei sobborghi della città. L'incontro con i giovani e seminaristi nel Seminario Saint Joseph a New York, 19.01.2008, „Insegnamenti" 4 (2008) 1, s. 651-652; La fede non solo ha un futuro, ma è futuro. L'incontro con il clero di Bolzano-Bressanone, 6.08.2008, „Insegnamenti” 4 (2008) 2, s. 115. 
pokory, tolerancji, przebaczenia i wyrozumiałości wobec innych. Papież pisze: „Również sakrament pokuty jest ważny. Uczy mnie patrzeć na siebie z Bożego punktu widzenia, zmusza mnie do uczciwości w stosunku do siebie. Wskazuje mi drogę do pokory. Proboszcz z Ars powiedział kiedyś: Myślicie, że nie ma sensu otrzymanie dziś rozgrzeszenia wiedząc, że jutro znów popełnicie te same grzechy. Jednak - mówi - Bóg sam zapomina $\mathrm{w}$ tym momencie o waszych jutrzejszych grzechach, by dać wam łaskę dziś. Chociaż musimy nieustannie walczyć z tymi samymi błędami, ważne jest przeciwstawianie się zeszpeceniu duszy, obojętności, która godzi się z tym, że tacy już jesteśmy. Ważne jest, by wciąż być w drodze, bez zbędnej skrupulatności, z pełną wdzięczności świadomością, że Bóg wciąż na nowo mi przebacza, ale i bez obojętności, która nie pozwoliłaby walczyć o świętość i o poprawę. A dając sobie przebaczyć, uczę się także przebaczać innym. Uznając, że jestem nędzny, staję się bardziej tolerancyjny i wyrozumiały dla słabości bliźniego" ${ }^{\prime 6}$.

Z sakramentem pokuty łączy się ściśle kierownictwo duchowe. Praktyki tej, podobnie jak cnoty pokuty, powinni się uczyć alumni podczas formacji seminaryjnej. Wskazuje na to wyraźnie Ratio fundamentalis institutionis sacerdotalis: „niech każdy z alumnów ma swego kierownika duchowego, przed którym z pokorą i zaufaniem będzie otwierał swoje sumienie, aby pewniej mógł podążać drogą Pana. Alumni niech z całkowitą swobodą wybiorą sobie kierownika duchowego i spowiednika spośród kapłanów, których Biskup wyznaczył jako odpowiednich do tego zadania" ${ }^{65}$.

Również Jan Paweł II zauważa w Pastores dabo vobis, iż: „Trzeba koniecznie odkryć na nowo wielką tradycję osobistego kierownictwa duchowego, które zawsze przynosiło liczne i cenne owoce w życiu Kościoła. W konkretnych przypadkach i przy spełnieniu ściśle określonych warunków może ono być wspomagane, ale nie zastępowane, przez pewne formy analizy czy pomocy psychologicznej"66.

Wreszcie w formacji duchowej seminarzystów należy zwrócić uwagę na zaszczepienie w nich pobożności maryjnej. Miłość alumna do Maryi powinna opierać się na wierze i wyrażać w codziennym odmawianiu Różańca świętego, naśladowaniu Jej cnót i pełnym Jej zawierzeniu.

${ }^{64}$ Tenże, List do Seminarzystów, n. 3, p. 5.

${ }^{65}$ Ratio fundamentalis institutionis sacerdotalis, n. 55 - tłum. własne; por. także, Congregazione per l'Educazione Cattolica, Lettera circolare su alcuni aspetti piu urgenti della formazione spirituale nei seminari, 6.01.1980, w: EV 7, n. 77-78.

${ }^{66}$ Pastores dabo vobis, n. 40. 


\subsection{FORMACJA INTELEKTUALNA}

Dzisiaj kapłan wezwany jest do głoszenia Ewangelii światu często obojętnemu na wartości religijne oraz do rozwiązywania różnorodnych i złożonych problemów ludzkich. Z tego względu formacja intelektualna powinna prezentować wysoki poziom naukowy i być pielęgnowana z największą starannością ${ }^{67}$.

Formacja ta, aby była skutecznym narzędziem integralnej formacji przyszłego kapłana musi najpierw zapewnić mu właściwe przygotowanie filozoficzne. Ratio fundamentalis institutionis sacerdotalis przypisuje temu przygotowaniu szczególne znaczenie ze względu na studium teologii, jak również na konieczność podjęcia owocnego dialogu ze współczesnym człowiekiem: "Jest rzeczą oczywistą, iż studia filozoficzne zarówno ze względu na postawione sobie cele, jak i współczesną sytuację wymagającą kompletnej formacji nie tylko nie są obce poszukiwaniu i przekazywaniu wiary, lecz, przeciwnie, wnoszą w ten proces cenny wkład"68.

Wielkie znaczenie studium filozofii $\mathrm{w}$ formacji kapłańskiej dostrzega również Kodeks Prawa Kanonicznego. Stwierdza on: „Kształcenie filozoficzne, które ma się oprzeć na wiecznie trwałym dziedzictwie filozoficznym, uwzględniającym również współczesne badania filozoficzne, ma się tak odbywać, by doskonaliło formację humanistyczną alumnów, ćwiczyło umysł i przygotowywało ich do podjęcia studiów teologicznych"69.

Po tej linii idzie także Adhortacja apostolska Pastores dabo vobis, która uważa filozofię za konieczną w poszukiwaniu prawdy i lepszego zrozumienia tożsamości i powołania kapłańskiego: „Nie trudno zrozumieć, że niektóre bardzo konkretne kwestie - jak tożsamość kapłana i jego zaangażowanie apostolskie i misyjne - są głęboko związane $\mathrm{z}$ bynajmniej nie abstrakcyjnym problemem prawdy. Jeśli się nie jest pewnym prawdy, jak można położyć na szali całe swoje życie i znaleźć siłę, by stawiać poważne pytania dotyczące życia innych ludzi?"70.

${ }^{67}$ Por. Benedykt XVI, List do Seminarzystów, n. 5, s. 6.

${ }^{68}$ Ratio fundamentalis institutionis sacerdotalis, n. 70, nota 148 a - tłum. własne; por. także, Optatam totius, n. 14-15, AAS 58 (1966) 722: tłum. pol., w: Sobór Watykański II, Konstytucje, Dekrety, Deklaracje, s. 296-297; Jan Paweł II, Encyklika Fides et ratio, 14.09.1998, Watykan 1998, n. 60; Congregazione per l'Educazione Cattolica, Lettera circolare, L'insegnamento della filosofia nei seminari, 20.01.1972, Libreria Editrice Vaticana 1972.

${ }^{69}$ Kodeks Prawa Kanonicznego, kan. 251.

${ }^{70}$ Pastores dabo vobis, n. 52. 
Formacja intelektualna oprócz zagwarantowania kandydatowi do kapłaństwa właściwego przygotowania filozoficznego winna również zaofiarować mu solidne przygotowanie teologiczne. Przygotowanie to powinno pomóc seminarzyście $\mathrm{w}$ "ukształtowaniu własnej wizji prawd objawionych przez Boga w Jezusie Chrystusie i doświadczenia wiary Kościoła, wizji petnej $i$ scalonej"71. Stąd przyszłemu kapłanowi trzeba umożliwić poznanie „wszystkich prawd wiary chrześcijańskiej” i poznania ich w "sposób organiczny”. Należy mu zatem pomóc w „dokonaniu syntezy, ogarniającej wkład różnych dyscyplin teologicznych, których specyfika nabiera autentycznej wartości jedynie w ich głębokim wzajemnym powiązaniu"72.

W formacji intelektualnej seminarzystów trzeba ponadto uwzględnić kontekst kulturowy, który stanowi dzisiaj dla Kościoła wielkie wyzwanie. Szczególnie powinno się zwrócić uwagę na ekumenizm, nauki ścisłe i przyrodnicze, wielkie problemy etyczne, sekularyzację wiary, agnostycyzm, problem sprawiedliwości społecznej, pokoju i wolności ${ }^{73}$.

Nie ulega wątpliwości, iż tylko tak ukierunkowana formacja filozoficzno-teologiczna może pomóc przyszłemu kapłanowi do pogłębionego poznania Bożych tajemnic i do skutecznego podjęcia wyzwań nowej ewangelizacji.

\subsection{FORMACJA DUSZPASTERSKA}

Formacja duszpasterska stanowi ukoronowanie całej formacji kapłańskiej. Prawda ta została potwierdzona już w soborowym Dekrecie Optatam totius: „Kształcenie [...] alumnów powinno w całości zmierzać do tego, by stawali się oni prawdziwymi duszpasterzami na wzór Pana naszego Jezusa Chrystusa, Nauczyciela, Kapłana i Pasterza"74.

Również Jan Paweł II podkreśla, że wszelka działalność kapłana a więc i cała formacja duszpasterska - zmierzają do „udziału w miłości

${ }^{71}$ Tamże; por. także, Benedykt XVI, List do Seminarzystów, n. 5, s. 6.

72 Pastores dabo vobis, n. 52.

${ }^{73}$ Por. tamże, n. 54; por. także, Benedykt XVI, List do Seminarzystów, n. 5, s. 6; C. M. Martini, Qualche anno dopo. Riflessioni sul ministero presbiterale, Casale Monferrato 1987, s. 21.

${ }^{74}$ Optatam totius, n. 4, AAS 58 (1966) 716: tłum. pol., w: Sobór Watykański II, Konstytucje, Dekrety, Deklaracje, s. 291. 
Chrystusa Dobrego Pasterza"75. Ponadto zauważa on: „Cel duszpasterski [...] integruje i kształtuje całą formację przyszłych kapłanów"76.

Formacja duszpasterska przyszłych kapłanów obejmuje aspekt teoretyczny i praktyczny.

Aspekt teoretyczny stanowi specyficzna refleksja teologiczna, której właściwym przedmiotem jest teologia pastoralna, zwana także praktyczną. Jest to refleksja analityczno-krytyczna nad rozwojem działalności duszpasterskiej Kościoła i działania chrześcijanina w różnych kontekstach społeczno-kulturowych naszych czasów, aby ukazać jego autentyczność i skuteczność, aspekty pozytywne, problematyczne i negatywne. Ponadto pragnie ona ukazać środki do uczynienia kościelnego działania duszpasterskiego skuteczniejszym i bardziej odpowiadającym duchowi czasów ${ }^{77}$.

Refleksja ta obejmuje między innymi takie dyscypliny naukowe, jak teologię pastoralną w ścisłym słowa tego znaczeniu, katechetykę, homiletykę, prawo kanoniczne itd. Następnie jest ona uzupełniana różnymi elementami interdyscyplinarnymi przedstawiającymi implikacje duszpasterskie eklezjologii, sakramentologii i teologii moralnej. Wykorzystuje ponadto w odpowiedni sposób osiągnięcia takich nauk, jak pedagogika, metodologia, socjologia, psychologia, które pozwalają poznać lepiej potrzeby osobiste, społeczne i religijne ludzi; złożoność środowisk apostolatu; środki pedagogiczne i metodologiczne użyteczne w duszpasterstwie. Dyscypliny te, jednakże, powinny być uważane za pomocnicze w tym znaczeniu, iż dotyczą aspektu ludzkiego fenomenu religii, podczas gdy on składa się głównie z elementów nadprzyrodzonych wykraczających poza obszar poszukiwań nauk humanistycznych ${ }^{78}$.

Aspekt praktyczny formacji duszpasterskiej stanowią z kolei różnego typu praktyki duszpasterskie alumnów. Powinny być one dobierane z wielką roztropnością, nie improwizowane, lecz rzetelnie przygotowane, dozowane stopniowo w zależności od zdolności seminarzystów, dokładnie zaprogramowane w czasie, odbywane zgodnie z dyrektywami współpracujących kapłanów i świeckich, odpowiednio kontrolowane i kierowane przez samych wychowawców lub przez osoby wykwalifikowane, posiadające doświadczenie apostolskie i umiejętność właściwego przewodniczenia wspólnotom chrześcijańskim.

\footnotetext{
${ }^{75}$ Pastores dabo vobis, n. 57.

76 Tamże.

77 Por. A. Favale, La formazione iniziale dei candidati al presbiterato, Roma 1995, s. 97.

${ }^{78}$ Por. tamże.
} 
Ponadto, ze strony wychowawców odpowiedzialnych za formację, jak i ze strony alumnów, powinno istnieć pragnienie i wola harmonizowania praktyk duszpasterskich $\mathrm{z}$ całym procesem formacyjnym $\mathrm{w}$ taki sposób, aby zaangażowanie $\mathrm{w}$ studium i postęp $\mathrm{w}$ całościowej formacji nie tylko nie były zakłócane, lecz umacniane i scalane tymi aspektami, których wspólnota seminaryjna nie może zaoferować w perspektywie przyszłych zadań. Takie zharmonizowanie może być ułatwione, jeśli praktyki duszpasterskie będą omawiane i oceniane przez samych zainteresowanych $\mathrm{z}$ ich wychowawcami, albo jeszcze lepiej $\mathrm{w}$ grupie $^{79}$.

W tym kontekście należy zauważyć, iż praktyki duszpasterskie są bardzo owocne $\mathrm{w}$ końcowej fazie studiów, kiedy seminarzysta posiada już solidny bagaż wiadomości i dobrego przygotowania duchowego, natomiast $\mathrm{w}$ pierwszych latach seminaryjnych są najczęściej bezużyteczne i mogą stać się przeszkodą w pogłębieniu formacji.

\section{STARANNIE WYBRANI I PRZYGOTOWANI WYCHOWAWCY SEMINARYJNI GWARANCJĄ SOLIDNEJ FORMACJI KAPŁAŃSKIEJ}

Wizytacje Apostolskie wykazały $\mathrm{w}$ wielu seminariach - i to w różnych krajach - iż ekipy wychowawców są niekompletne. Brakuje w nich wicerektorów, prefektów studiów, ojców duchownych. Niekiedy wychowawcy pełnią jednocześnie różne funkcje $w$ diecezji, mieszkają poza seminariami i dochodzą do nich tylko w niektóre dni tygodnia. Zauważa się też, że wielu wychowawców jest bardzo młodych, bez żadnego specyficznego przygotowania do wykonywania powierzonych im funkcji wychowawczych oraz nie posiadają żadnego doświadczenia duszpasterskiego. Jest zaś rzeczą oczywistą, iż wychowawcy seminaryjni mają wielki wpływ na losy seminarium, a w związku z tym na jakość formacji przyszłych kapłanów. Jacy wychowawcy, takie seminaria, taka i formacja integralna seminarzystów. Seminaria duchowne, aby mogły zapewnić alumnom solidną formację, muszą dysponować odpowiednią liczbą wychowawców starannie dobranych, właściwie przygotowanych i przepojonych ideałami kapłańskimi.

${ }^{79}$ Por. Pastores dabo vobis, n. 57; por. także, A. Favale, La formazione iniziale dei candidati al presbiterato, s. 100. 


\subsection{KRYTERIA WYBORU WYCHOWAWCÓW}

Kryteria, według których winni być wybierani wychowawcy przyszłych kapłanów, są bardzo wymagające.

Soborowy Dekret o formacji kapłańskiej Optatam totius stwierdza: „Ponieważ formacja alumnów zależy zarówno od mądrych przepisów, jak i w najwyższej mierze od odpowiednich wychowawców, przełożeni i profesorowie seminariów winni być dobierani spośród najlepszych" ${ }^{\prime 80}$.

Ratio fundamentalis institutionis sacerdotalis kontynuując myśl soborową dodaje: „Przełożeni winni być wybierani z największą starannością. Powinni być ożywieni duchem kapłańskim i apostolskim, zdolnymi do wzajemnej i braterskiej współpracy we wspólnym działaniu wychowawczym, wrażliwymi i otwartymi na potrzeby wspólnoty kościelnej i świeckiej, odznaczającymi się doświadczeniem duszpasterskim w posłudze parafialnej lub innych posługach, doskonałymi znawcami młodzieńczego ducha" ${ }^{\prime \prime 1}$.

Temat ten podjął również Jan Paweł II w Adhortacji apostolskiej Pastores dabo vobis. Wspominając wymagania soborowe, zaakcentował on jeszcze bardziej rys kolegialny i duchowy formatorów: „Z pewnością - stwierdza Papież, cytując Ojców Synodalnych - zadanie formacji kandydatów do kapłaństwa wymaga nie tylko specjalnego przygotowania formatorów [...], ale także ducha wspólnoty i współpracy oraz zgodnej realizacji programu, tak aby zawsze była zachowana jedność duszpasterskiego działania seminarium pod kierunkiem rektora. Niech wychowawcy dają świadectwo prawdziwie ewangelicznego życia i całkowitego oddania się Panu. Należy zadbać o to, by ich życie odznaczało się pewną stabilnością oraz by mieszkali razem $\mathrm{z}$ całą wspólnotą seminarium. Niech będą ściśle złączeni z biskupem, który jako pierwszy jest odpowiedzialny za formację kapłanów"1"82.

Według Kongregacji Edukacji Katolickiej u kandydata na wychowawcę należy rozróżnić między "charyzmatem", który wiąże się z jego predyspozycjami wrodzonymi i będącymi owocami łaski Bożej a zdolnościami, które nabył podczas studiów i praktyki.

${ }^{80}$ Optatam totius, n. 5, AAS 58 (1966) 716: tłum. pol., w: Sobór Watykański II, Konstytucje, Dekrety, Deklaracje, s. 291.

${ }^{81}$ Ratio fundamentalis institutionis sacerdotalis, n. 30 - tłum. własne.

${ }^{82}$ Pastores dabo vobis, n. 66. 
O wyborze wychowawcy powinny decydować także takie jego przymioty, jak: głęboka wiara, zmysł duszpasterski, duch wspólnoty, dojrzałość ludzka i równowaga psychiczna, dojrzałość uczuciowa, komunikatywność, pozytywne i krytyczne spojrzenie na współczesną kulturę $\varepsilon^{83}$.

\subsection{PRZYGOTOWANIE WYCHOWAWCÓW}

Wychowawcy seminaryjni oprócz tego, iż powinni być starannie wybrani, winni posiadać solidne przygotowanie.

Sprawa przygotowania wychowawców została podjęta już na Soborze Watykańskim II. Dekret Optatam totius wymaga, aby wychowawcy seminaryjni byli „starannie przygotowani przez gruntowne wykształcenie, odpowiednie doświadczenie duszpasterskie i właściwe ukształtowanie duchowe i pedagogiczne" 84 . Dokument ten sugeruje również aby „ustanawiać instytuty, a przynajmniej kursy, o odpowiednim programie przygotowawczym, a także urządzać regularne spotkania przełożonych seminariów" ${ }^{\prime \prime 5}$.

Wymagania te zostały ponownie podjęte $\mathrm{w}$ niektórych zaleceniach nadzwyczajnego Synodu Biskupów w 1967 roku, a następnie sformułowane $\mathrm{w}$ Ratio fundamentalis institutionis sacerdotalis. $\mathrm{W}$ dokumencie tym czytamy: „Misja przełożonych seminaryjnych będąc sztuką nad sztukami nie pozwala na działanie $\mathrm{w}$ sposób improwizacyjny i przypadkowy. Stąd, oprócz przymiotów naturalnych i nadprzyrodzonych winni oni koniecznie posiadać, w zależności od powierzonego zadania, odpowiednie przygotowanie duchowe, pedagogiczne i fachowe, nabyte przede wszystkim $\mathrm{w}$ wyspecjalizowanych instytutach, erygowanych lub mających być erygowanymi w tym celu we własnym kraju lub w innych krajach"86.

Podstawowym jednak dokumentem odnośnie formacji formatorów są Wskazania dotyczące przygotowania wychowawców w Seminariach. Przedstawia on szczegółowo wymogi i kierunki formacji formatorów. Formacja ta zawiera fazę wstępną, początkową, poprzedzającą - o ile to

${ }^{83}$ Por. Congregazione per l'Educazione Cattolica, Direttive sulla preparazione degli educatori nei Seminari, 4.11.1993, Roma 1993, n. 24-42.

${ }^{84}$ Optatam totius, n. 5, AAS 58 (1966) 716-717: tłum. pol., w: Sobór Watykański II, Konstytucje, Dekrety, Deklaracje, s. 291; zob. też Pastores dabo vobis, n. 66.

${ }^{85}$ Optatam totius, n. 5, AAS 58 (1966) 717: tłum. pol., w: Sobór Watykański II, Konstytucje, Dekrety, Deklaracje, s. 291-292.

${ }^{86}$ Ratio fundamentalis institutionis sacerdotalis, n. 30 - tłum. własne. 
możliwe - podjęcie obowiązków oraz fazę dalszą, okresowo ponawianą, czyli formację stałą ${ }^{87}$.

W tym kontekście należy podkreślić, iż w skali światowej sposoby realizacji formacji formatorów są zróżnicowane. W wielu krajach Konferencje Biskupie organizują przeróżne spotkania, konferencje czy sympozja poświęcone tematyce formacyjnej. Ponadto organizowane są specjalne Szkoły Formatorów, przeprowadzające okresowe cykle formacyjne dla ojców duchownych i moderatorów zewnętrznych.

W Polsce od 10 stycznia 2005 roku działa, pod patronatem Komisji Episkopatu Polski ds. Duchowieństwa, Szkoła Wychowawców Seminariów Duchownych Diecezjalnych i Zakonnych. Jest ona prowadzona w Centrum Formacji Duchowej Salwatorianów w Krakowie. W dwuletnim cyklu formacyjnym biorą udział rektorzy, prefekci, ojcowie duchowni, mistrzowie nowicjatu i postulatu z Polski i z krajów Europy Wschodniej.

Jeśli zaś chodzi o incjatywy promujące formację formatorów i mające charakter ogólnokościelny, do najważniejszych należy zaliczyć dwie, organizowane we Włoszech.

Pierwsza z nich to kurs organizowany corocznie przez Legionistów Chrystusa, za pośrednictwem Papieskiego Ateneum Regina Apostolorum. Trwa on miesiąc czasu i przeznaczony jest dla formatorów seminaryjnych pochodzących ze wszystkich kontynentów.

Druga inicjatywa jest promowana przez Kongregację Edukacji Katolickiej we współpracy z Instytutem Duchowości i Psychologii Papieskiego Uniwersytetu Gregoriańskiego w Rzymie. Jest to kurs interdyscyplinarny dla formatorów seminarzystów, młodych księży i osób konsekrowanych. Kurs jest roczny i kończy się uzyskaniem dyplomu. Kto chce, może - uzupełniając przedmioty i po napisaniu pracy (dwa lata studiów) - otrzymać licencjat z teologii duchowości ze specjalizacją w formacji kapłańskiej.

$* * *$

Podsumowując, należy zauważyć, iż przyszłość Kościoła i skuteczność jego misji we współczesnym świecie zależą od świadectwa wiernych w ścisłej łączności z biskupami i kapłanami, którzy we wspólnotach kościelnych pełnią funkcję animatorów. Stąd Kościół musi podejmować nieustanne wysiłki, aby zagwarantować przyszłym kapłanom solidną i kompletną formację. Formacja ta powinna być prowadzona przez wła-

${ }^{87}$ Por. Direttive sulla preparazione degli educatori nei Seminari, n. 48-71. 
ściwie dobranych i dobrze przygotowanych wychowawców. Powinna też opierać się na koncepcji kapłaństwa całkowicie zgodnej z nauczaniem Kościoła i obejmować wymiar ludzki, duchowy, intelektualny i duszpasterski. Ponadto należy zwrócić uwagę na staranne rozeznanie zdatności kandydatów zarówno przy przyjmowaniu ich do seminarium jak też przy dopuszczaniu do święceń. Nie ulega wątpliwości, iż tylko w taki sposób będzie można uformować kapłanów, prawdziwych świadków Ewangelii, wszechstronnie przygotowanych, dyspozycyjnych, inspirowanych autentyczną miłością pasterską, wspieranych pogłębioną duchowością, ożywionych miłością do Kościoła, jednym słowem zdolnych do owocnego podjęcia nowej ewangelizacji.

\section{ATTUALI ASPETTI DELLA FORMAZIONE DEI FUTURI SACERDOTI}

\section{RIASSUNTO}

Le ricerche sociologiche dimostrano chiaramente che oggi per il sacerdote è molto piủ difficile svolgere le attività pastorali che ancora qualche decina di anni fa. Le cause di tale situazione sono diverse: il relativismo morale, la complessa situazione socio-politica, spesso la presentazione della Chiesa in luce negativa dai mass media e le nuove e difficili sfide dei nostri tempi. Inoltre, oggi il sacerdote è piủ spesso esposto agli insuccessi nel compimento della sua missione. Di fronte a tali difficoltà alcuni sacerdoti prendono la drammattica decisione di lasciare il sacerdozio. In questa situazione l'adeguata formazione dei futuri sacerdoti, per continuare fruttuosamente e fedelmente la missione di Gesů Buon Pastore nel mondo contemporaneo, costituisce uno dei piů importanti compiti della Chiesa. Tale formazione dovrebbe essere solida e completa e affidata a formatori scelti con attenzione e ben preparati. La formazione seminaristica dovrebbe basarsi su un concetto del sacerdozio pienamente conforme con l'insegnamento della Chiesa ed abbracciare la dimensione umana, spirituale, intellettuale e pastorale. Si deve dare anche attenzione per accurato discernimento dell'idoneità dei candidati al sacerdozio sia nel momento dell'ammissione al Seminario sia nella promozione agli Ordini Sacri. E' ovvio che soltanto in questo modo sarà possibile formare sacerdoti che siano veri testimoni del Vangelo, ben preparati, disponibili, ispirati dall'autentico amore pastorale, fondati su un'approfondita spiritualità, animati dall'amore per la Chiesa, insomma capaci di riprendere in modo efficace i compiti della nuova evangelizzazione. 